\title{
Influence of Wood Moisture Content on the Modulus of Elasticity in Compression Parallel to the Grain
}

\author{
Diogo Aparecido Lopes Silva*, Francisco Antonio Rocco Lahr ${ }^{\mathrm{b}}$, \\ Obede Borges de Faria ${ }^{\mathrm{c}}$ Eduardo Chahud ${ }^{\mathrm{d}}$ \\ ${ }^{a}$ Interunit Area of Materials Science and Engineering, University of São Paulo - USP, \\ Av. Trabalhador São-carlense, 400, Centro, CEP 13566-590, São Carlos, SP, Brazil \\ ${ }^{\mathrm{b}}$ São Carlos School of Engineering, University of São Paulo - USP, \\ Av. Trabalhador São-carlense, 400, Centro, CEP 13566-590, São Carlos, SP, Brazil \\ ${ }^{\mathrm{c}}$ Bauru College of Engineerring, Paulista State University - UNESP, \\ Av. Engenheiro Luiz Edmundo C.Coube, 14-01, CEP 17033-360, Bauru, SP, Brazil \\ ${ }^{\mathrm{d} C o l l e g e ~ o f ~ E n g i n n e r i n g ~ a n d ~ A r c h i t e c t u r e, ~ F u n d a c ̧ a ̃ o ~ M i n e i r a ~ d e ~ E d u c a c ̧ a ̃ o ~ e ~ C u l t u r a ~-~ F U M E C, ~}$ \\ Rua Cobre, 200, Cruzeiro, CEP 30310-190, Belo Horizonte, MG, Brazil
}

Received: September 6, 2011; Revised: January 20, 2012

\begin{abstract}
Brazilian Standard ABNT NBR7190:1997 for timber structures design, adopts a first degree equation to describe the influence of wood moisture content. Periodically, when necessary, the referred standard is revised in order to analyze inconsistencies and to adopt considerations according new realities verified. So, the present paper aims to examine the adequacy of its equation which corrects to $12 \%$ of moisture the values of rigidity properties obtained on experimental tests. To quantify the moisture influence on modulus of elasticity, it was applied tests of compression parallel to the grain for six specimens of different strength classes, considering nominal moisture of $12 ; 20 ; 25 ; 30 \%$. As results, modulus of elasticity in the moisture range $25-30 \%$ showed statistically equivalents, and was obtained a first degree equation to correlate the studied variables which leads to statically equivalent estimations when compared with results by ABNT NBR7190:1997 equation. However, it was indicated to maintain the current expression for the next text of the referred document review, without prejudice to statistical significance of the estimates.
\end{abstract}

Keywords: wood, moisture content, modulus of elasticity, compression parallel to the grain

\section{Introduction}

The increasing demand for materials from renewable sources has been shown irrevocably nowadays. It happens due the action of several driving forces such as increasing scarcity of natural resources, the need to reduce the environmental impacts in human activities, and evolution of consumer's profile that values more and more the socioenvironmental issues.

The wood besides belonging from renewable resources, it's one of the most popular materials used in construction sector. In the scope of construction, the wood shows particularly interesting for many different purposes, as in the roof structures, window frames, temporary uses such as concrete forms, scaffolding, among other applications of the genre. For this goal, is necessary the complete knowledge of its physico-mecanical properties.

For the timber structures design, is fundamental to know the wood strength and rigidity. However, these are influenced by moisture content under the fiber saturation point. Many researchers have dedicated to study the issue and brought their contributions to quantify the cited influence, usually considering normative documents on the subject.

*e-mail: diogo.apls@hotmail.com
According to the Brazilian Standard ABNT NBR7190:1997 ${ }^{[1]}$ for timber structures design, it is recognized the importance of the moisture influence on the properties of wood for structural purposes. This recognition is translated by adoption coefficients that modify parameters of wood strength and rigidity, and also recommending the use of first degree equation to adjust reference moisture percentage (12\%) for material properties obtained at lab tests. These recommendations from Brazilian Standard are based on experimental results. Thus, in order to increase the knowledge about this experimental data, it is convenient, where possible, to confirm the reality of expression adopted by the mentioned code.

This paper from compression parallel tests, initially quantify the moisture influence on modulus of elasticity of wood species, for three different strength classes (C60, C40 e C30) by ABNT NBR 7190:1997. In this way, according to data collected, this study aims is to confirm the adequacy of ABNT NBR7190:1997 equation which corrects to $12 \%$ of moisture content the values of modulus of elasticity obtained on experimental tests. 


\section{Literature Review}

It is known that water content in wood interferes on its physical and mechanical properties directly. The determination of moisture and its influence on wood properties are essential, especially in the characterization of wood species, targeting their best application.

Knowledge about the influence of moisture on the strength properties of wood is a subject that many researchers have been occupied over the years. Wilson', MacLain ${ }^{3}$, Mateus ${ }^{4}$, Kollmann and Cote ${ }^{5}$, Parker ${ }^{6}$, Hellmeister $^{7}$, and Ozelton Baird ${ }^{8}$ and Pigozzo ${ }^{9}$ are among the first who brought interesting contributions on the subject in order to discuss and quantify the influence of moisture on physical and mechanical wood properties, with emphasis on dimensional stability, resistance to different solicitations, and specific gravity.

Publications about the influence of moisture on stiffness properties are less numerous. As examples, the Boletim $31^{[10]}$ from Institute for Technological Research - IPT brings properties values for more than two hundred species of wood grown in Brazil. The rigidity properties are given just for saturated wood and the influence of moisture wasn't discussed.

Bolza and Kloot ${ }^{11}$ have studied properties of one hundred and seventy four wood species in Australia, being many of them for saturated wood and $12 \%$ moisture. But, these authors haven't established relations between the moisture and any other property. Other similar considerations about the wood properties are available in literature, as Chudnoff ${ }^{12}$; Rocco Lahr and Robles ${ }^{13}$, Rocco Lahr and Dias ${ }^{14}$; Souza ${ }^{15}$; Zenid and Costa $^{16}$; Finger et al. ${ }^{17,18}$ and Trevisan et al. ${ }^{19}$. The influence of moisture on the mechanical wood properties wasn't an objective of evaluation on these papers.

About researches on wood properties, stand out studies related to compression parallel to the grain, cause this is one of the major references in the timber elements design. The wood in compression parallel to the grain tests behaves ductile, not breaking catastrophically, and also provides strength levels that are among the highest for the material performance.

Thus, many national authors are researching the wood properties in compression parallel to the grain, for example, Pigozzo 9 , Ballarin and Ribeiro ${ }^{20}$, Serpa et al..$^{21}$, Lobão et al. ${ }^{22}$ and Mascia and Rocco Lahr ${ }^{23}$. These authors didn't refer the relation between moisture content and modulus of elasticity, but bring their contributions to the expansion of knowledge of wood properties and technology.

The following are commented publications directly related to the theme of this work, where the relation moisture-rigidity is developed.

Tanaami ${ }^{24}$ proposes an equation to relate the moisture content $(U)$, the specific gravity $(\rho)$ and the characteristic longitudinal modulus of elasticity $\left(\mathrm{E}_{\mathrm{k}}\right)$. Below is the equation, where $\mathrm{E}_{\mathrm{k}}$ is given in $\mathrm{MPa}$ and $\mathrm{U}$ in $\%$.

$E_{k}=-78 U+11239$

Equation 1 shows that the moisture content and wood modulus of elasticity are related. When increasing $U$ values, there is a proportional and constant decrease of $E_{k}$, according a first degree equation.
Rocco Lahr ${ }^{25}$ assessing the behavior of dicotyledon woods, determined there is significant increase in the coefficient of variation of modulus of elasticity when moisture passes 30 to $12 \%$. On the other hand, it wasn't developed any expression to relate the modulus of elasticity and moisture.

Faria ${ }^{26}$ working with six wood species, presented a model to correlate the modulus of elasticity and the moisture content. Equation 2 enunciated below, was obtained from experimental results from bending tests.

$$
\frac{E_{u}}{E_{30}}=1,30-0,01 U
$$

In Equation $2 \mathrm{E}_{\mathrm{u}}$ is the value of the modulus of elasticity for the percentage of moisture $\mathrm{U}$, and $\mathrm{E}_{30}$ is the value of the same property for $30 \%$ wood moisture content.

Logsdon ${ }^{27}$ has proposed Equation 3 to correct the values of the properties of strength and rigidity of wood to the reference moisture $12 \%$, based on specimens of seven species of wood representing the seven classes of resistance described on ABNT NBR 7190:1997[1].

$$
E_{12}=E_{U}\left[1+\frac{2,5(U-12)}{100}\right] \text { or } \frac{E_{12}}{E_{u}}=\left[1+\frac{2,5(U-12)}{100}\right]
$$

The term accepted by the Brazilian Standard ABNT NBR 7190:1997 is analogous to Equation 3. However, adopts coefficient of 2 instead of 2.5 , according to Equation 4.

$$
E_{12}=E_{U}\left[1+\frac{2(U-12)}{100}\right] \text { or } \frac{E_{12}}{E_{u}}=\left[1+\frac{2(U-12)}{100}\right]
$$

After the brief account of references about the research topic, it's important mentioning that this paper contributes to extend knowledge on the subject, based on experimental data resultants from Brazilian Standard recommendations.

\section{Experimental Procedures}

\subsection{Materials}

Six tropical dicotyledon species were used in this study as showed in Table 1, rated according to ABNT NBR7190:1997 ${ }^{[1]}$ strength classes. All species are qualified for structural purpose.

The wood pieces were acquired at market of the São Carlos city and the region, on two separate occasions. With this procedure was tried to ensure the randomness of the samples.

Table 1. Species and strength classes.

\begin{tabular}{lc}
\hline \multicolumn{1}{c}{ Species } & Strength classes \\
\hline Jatobá (Hymenaea stilbocarpa) & $\mathrm{C} 60$ \\
Maçaranduba (Manilkara sp.) & $\mathrm{C} 60$ \\
Canafístula (Cássia ferruginea) & $\mathrm{C} 40$ \\
Cupiúba (Goupia glabra) & $\mathrm{C} 40$ \\
Branquilho (Terminalia sp.) & $\mathrm{C} 30$ \\
Copaíba (Copaifera sp.) & $\mathrm{C} 30$ \\
\hline
\end{tabular}




\subsection{Methods}

The compression parallel to the grain tests were performed in consonance with the recommendations of Appendix B from ABNT NBR7190:1997[1]. For each of the six species was prepared a set of seven specimens. One of them was previously tested to rupture to the estimation of strength. Therefore, it was possible to ensure that in subsequent tests at any time would exceed the limit of proportionality of the material. It was necessary because the same specimen would be used to five tests, in 30, 25, 20 , and $12 \%$ of nominal moisture. The effective moisture of the specimens was controlled gravimetrically by oven drying. In all, were prepared 42 specimens and carried out 168 compression parallel tests.

The analysis of experimental results was conducted using generally accepted statistical procedures in such cases, involving the calculation of averages, standard deviations, as well as the procedures for linear regression and comparison test pairs by "pairing" tests with $95 \%$ confidence level. The "pairing" test determinate the confidence interval between two data sets. The distribution of " $\mathrm{t}$ " values was extracted by Meyer ${ }^{28}$ from Student's $t$-test.

The mechanical tests were performed at the Laboratory of Wood and Wood Structures - LaMEM, Department of Structural Engineering, School of Engineering of São Carlos. The statistical analysis was performed at the Faculty of Engineering and Architecture - FUMEC, Belo Horizonte both in Brazil.

\section{Results and Discussion}

Table 2 presents the average values of effective moisture $\mathrm{U}(\%)$, and modulus of elasticity $\mathrm{E}(\mathrm{MPa})$, for the compression parallel to the grain tests according to the six wood species and the five levels of moisture pre-established.

The results in Table 2 show that even with careful moisture control, the moisture percentages obtained for each specie introduced slight difference from the nominal values initially adopted. Moreover, as expected, the experimental results were superior to C60 strength class for Jatobá and Maçaranduba species, decreasing until the lowest rigidity results, obtained for the $\mathrm{C} 30$ class, where the Branquilho and Copaiba species belong.

To define the range of validity of experimental results, it was considered convenient to check whether the experimental values of $\mathrm{E}$ for the 25 and $30 \%$ nominal moisture could be considered statistically equivalents with $95 \%$ reliability. The statistical hypothesis of equivalence between the $\mathrm{E}$ values for 25 and $30 \%$ nominal moisture was evaluated using the "pairing" test. Table 3 summarizes the results found.

The results in Table 3 show that modulus of elasticity for 25 and $30 \%$ nominal moisture can be considered statistically equivalents. Thus, the range of validity of this study was changed for $12-25 \%$ nominal moisture, very close to that suggested by ABNT NBR7190:1997 ${ }^{[1]}$, between 10-20\%.

Applying the procedure of simple linear regression to the set data of rigidity for each wood specie, were obtained equations to relate the variables in the range between $12-25 \%$ moisture content. The equations were developed considering the same format those recommended in the text of ABNT NBR7190:1997 [1] and Logsdon ${ }^{27}$. Also, the number of tests for all wood species is equivalent, which allowed defining a single equation that summarized all the correlations made. Equation 5 shows the expression obtained, with $\mathrm{R}^{2}=0.92$.

$$
E_{12}=E_{U}\left[1+\frac{1,5(U-12)}{100}\right] \text { or } \frac{E_{12}}{E_{u}}=\left[1+\frac{1,5(U-12)}{100}\right]
$$

Based on the experimental results of rigidity for 25, 20 and 12\% nominal moisture, and considering the Equations 4 and 5, were estimated $\mathrm{E}_{12} / \mathrm{E}_{\mathrm{u}}$ ratios for all wood species studied. In this case, $\mathrm{E}_{12}$ relates values of modulus of elasticity for the reference moisture of $12 \%$, and $\mathrm{E}_{\mathrm{u}}$ values of modulus for moisture $U$ ( 25 or $20 \%$ ). Table 4 summarizes the average results found for the $\mathrm{E}_{12} / \mathrm{E}_{\mathrm{u}}$ ratio.

For the data in Table 4, a statistical analysis was applied to verify the hypothesis of equivalence for $\mathrm{E}_{12} /$ $\mathrm{E}_{\mathrm{u}}$ values, considering two different situations. The first one, comparing the ratios obtained from the experimental results (Exp) with the ratios estimated by Equation 4, and the second one, comparing the experimental values with the ratios estimated by Equation 5. Also in these cases was employed the "pairing" test, as recommended by Meyer ${ }^{28}$. Tables 5 and 6 summarize the results from the statistical tests.

Table 3. Confidence intervals of average differences: E (MPa) for 25 and $30 \%$.

\begin{tabular}{lcl}
\hline \multicolumn{1}{c}{ Species } & Confidence interval & \multicolumn{1}{c}{ Conclusion } \\
\hline Jatobá & $-306 \leq \mu \leq+46$ & Statistically equivalents \\
Maçaranduba & $-440 \leq \mu \leq+427$ & Statistically equivalents \\
Canafístula & $-380 \leq \mu \leq+83$ & Statistically equivalents \\
Cupiúba & $-295 \leq \mu \leq+66$ & Statistically equivalents \\
Branquilho & $-530 \leq \mu \leq+101$ & Statistically equivalents \\
Copaíba & $-325 \leq \mu \leq+77$ & Statistically equivalents \\
\hline
\end{tabular}

Table 2. Average results of moisture (\%) and modulus of elasticity (MPa) per specie chosen.

\begin{tabular}{|c|c|c|c|c|c|c|c|c|}
\hline \multirow[t]{2}{*}{ Species } & \multicolumn{2}{|c|}{ Test one } & \multicolumn{2}{|c|}{ Test two } & \multicolumn{2}{|c|}{ Test three } & \multicolumn{2}{|c|}{ Test four } \\
\hline & $\mathrm{U}_{30}(\%)$ & E (MPa) & $\mathrm{U}_{25}(\%)$ & E (MPa) & $\mathrm{U}_{20}(\%)$ & E (MPa) & $\mathrm{U}_{12}(\%)$ & E (MPa) \\
\hline Jatobá & 30.6 & 15257 & 24.9 & 15387 & 20.0 & 15682 & 11.7 & 17204 \\
\hline Maçaranduba & 30.5 & 18261 & 24.6 & 18267 & 20.2 & 18689 & 11.9 & 19759 \\
\hline Canafístula & 30.3 & 11802 & 24.6 & 11951 & 19.8 & 12870 & 12.2 & 14442 \\
\hline Cupiúba & 29.2 & 11340 & 25.2 & 11455 & 19.6 & 12278 & 12.0 & 13396 \\
\hline Branquilho & 29.8 & 11434 & 25.1 & 11649 & 20.4 & 12912 & 11.6 & 14594 \\
\hline Copaíba & 30.5 & 8705 & 25.4 & 8829 & 19.8 & 10102 & 12.0 & 11913 \\
\hline
\end{tabular}


Table 4. E12/Eu ratios for the experimental results (Exp) and estimated by Equations 4 and 5 for the six species studied.

\begin{tabular}{lccccccc}
\hline \multirow{2}{*}{ Species } & \multicolumn{3}{c}{ Nominal U 25\% } & & \multicolumn{3}{c}{ Nominal U 20\% } \\
\cline { 2 - 3 } & $\mathbf{E}_{\mathbf{1 2}} / \mathbf{E}_{\mathbf{u}}(\mathbf{E x p})$ & $\mathbf{E}_{\mathbf{1 2}} / \mathbf{E}_{\mathbf{u}}(\mathbf{4})$ & $\mathbf{E}_{\mathbf{1 2}} / \mathbf{E}_{\mathbf{u}}(\mathbf{5})$ & & $\mathbf{E}_{\mathbf{1 2}} / \mathbf{E}_{\mathbf{u}}(\mathbf{E x p})$ & $\mathbf{E}_{\mathbf{1 2}} / \mathbf{E}_{\mathbf{u}}(\mathbf{4})$ & $\mathbf{E}_{\mathbf{1 2}} / \mathbf{E}_{\mathbf{u}}(\mathbf{5})$ \\
\hline Jatobá & 1.130 & 1.259 & 1.194 & & 1.097 & 1.159 & 1.120 \\
Maçaranduba & 1.084 & 1.253 & 1.190 & & 1.020 & 1.165 & 1.124 \\
Canafístula & 1.226 & 1.252 & 1.189 & & 1.138 & 1.155 & 1.116 \\
Cupiúba & 1.140 & 1.260 & 1.195 & & 1.064 & 1.151 & 1.113 \\
Branquilho & 1.241 & 1.262 & 1.197 & & 1.120 & 1.168 & 1.126 \\
Copaíba & 1.318 & 1.267 & 1.200 & & 1.152 & 1.157 & 1.118 \\
\hline
\end{tabular}

Table 5. Confidence intervals of average differences: E12/Eu (Exp) e E12/Eu (4).

\begin{tabular}{lccl}
\hline \multicolumn{1}{c}{ Species } & Confidence interval nominal U 25\% & Confidence interval nominal U 20\% & Conclusion \\
\hline Jatobá & $-0.234 \leq \mu \leq+0.005$ & $-0.125 \leq \mu \leq+0.010$ & Statistically equivalents \\
Maçaranduba & $-0.715 \leq \mu \leq+0.266$ & $-0.636 \leq \mu \leq+0.271$ & Statistically equivalents \\
Canafístula & $-0.130 \leq \mu \leq+0.071$ & $-0.103 \leq \mu \leq+0.064$ & Statistically equivalents \\
Cupiúba & $-0.172 \leq \mu \leq+0.025$ & $-0.184 \leq \mu \leq+0.014$ & Statistically equivalents \\
Branquilho & $-0.142 \leq \mu \leq+0.122$ & $-0.141 \leq \mu \leq+0.061$ & Statistically equivalents \\
Copaíba & $-0.104 \leq \mu \leq+0.200$ & $-0.106 \leq \mu \leq+0.089$ & Statistically equivalents \\
\hline
\end{tabular}

Table 6. Confidence intervals of average differences: E12/Eu (Exp) e E12/Eu (5).

\begin{tabular}{lccc}
\hline Species & Confidence interval nominal U 25\% & Confidence interval nominal U 20\% & Conclusion \\
\hline Jatobá & $-0.169 \leq \mu \leq+0.070$ & $-0.084 \leq \mu \leq+0.049$ & Statistically equivalents \\
Maçaranduba & $-0.638 \leq \mu \leq+0.354$ & $-0.595 \leq \mu \leq+0.313$ & Statistically equivalents \\
Canafístula & $-0.054 \leq \mu \leq+0.146$ & $-0.056 \leq \mu \leq+0.110$ & Statistically equivalents \\
Cupiúba & $-0.094 \leq \mu \leq+0.103$ & $-0.086 \leq \mu \leq+0.092$ & Statistically equivalents \\
Branquilho & $-0.064 \leq \mu \leq+0.201$ & $-0.092 \leq \mu \leq+0.112$ & Statistically equivalents \\
Copaíba & $-0.024 \leq \mu \leq+0.280$ & $-0.059 \leq \mu \leq+0.136$ & Statistically equivalents \\
\hline
\end{tabular}

It can be concluded from the confidence intervals shown in Tables 5 and 6 that the estimates of $\mathrm{E}_{12} / \mathrm{E}_{\mathrm{u}}$ are statistically equivalent to $95 \%$ confidence level, from comparison the experimental results with Equation 4, or with Equation 5, for the six wood species. Thus, both Equations 4 and 5 can be used to estimate the values of $\mathrm{E}_{12} / \mathrm{E}_{\mathrm{u}}$ as well as the values of $E_{12}$, from data $E_{u}$ for $U$ belonging to the range of moisture between $6-25 \%$.

\section{Conclusions}

This paper contributes to increase knowledge on the subject about wood properties and the influence of moisture, subsidizing decision-making about the normative parameters to adopt. In view of the results exposed about the influence of wood moisture content on modulus of elasticity from compression parallel to the grain tests, can be concluded that:
- Equation 4 (proposed by ABNT NBR 7190:1997) and Equation 5 (proposed in this paper) lead to estimates $\mathrm{E}_{12} / \mathrm{E}_{\mathrm{u}}$ statistically equivalent (at $95 \%$ confidence level) to those achieved from the experimental results for the six wood species studied, representing the strength classes with greatest potential for employment structural;

- Equation 5 is satisfactory to relate $\mathrm{E}_{12}$ and $\mathrm{E}_{\mathrm{u}}$ in the moisture range of 6-25\%. So, this new equation showed plausible to application in the timber structures design;

- But, even the satisfactory results from Equation 5 to correlate the influence of wood moisture in the modulus of elasticity in compression parallel to the grain, it's suggested to maintain the expression recommended by the ABNT NBR7190:1997 ${ }^{[1]}$ to relate $\mathrm{E}_{12} / \mathrm{E}_{\mathrm{u}}$ for the next text of the referred document review, without prejudice to statistical significance of the estimates. 


\section{References}

1. Associação Brasileira de Normas Técnicas - ABNT. NBR 7190: Projeto de Estruturas de Madeira. Rio de Janeiro: ABNT; 1997. $107 \mathrm{p}$.

2. Wilson TRC. Strength-moisture relations for wood. Washington; 1932. $88 \mathrm{p}$.

3. MacLain JD. Effect of heating in water on the strength properties of wood. Washington: American Wood Preservers Association; 1954. 120 p.

4. Mateus TJE. Bases para o dimensionamento de estruturas de madeira. Lisboa: LNEC; 1961. 308 p.

5. Kollmann FFP and Côté WA. Principles of wood science and technology. Springer Verlag; 1968. v. 1 Solid wood, 592 p.

6. Parker H. Diseño simplificado de estructuras de madera. México: Editorial Limusa-Wiley; 1972. 216 p.

7. Hellmeister JC. Sobre a determinação das características físicas da madeira. [Tese]. São Carlos:Escola de Engenharia de São Carlos, Universidade de São Paulo; 1973.

8. Ozelton EC and Baird JA. Timber designer's manual. Londres: Crosby Lock Wood Staples; 1976. 278 p.

9. Pigozzo JC. Influência da umidade e da densidade na resistência à compressão da madeira. [Dissertação]. São Carlos: Escola de Engenharia de São Carlos, Universidade de São Paulo; 1982.

10. Instituto de Pesquisas Tecnológicas do Estado de São Paulo. Madeiras nacionais: tabelas de resultados de ensaios físicos e mecânicos. São Paulo: IPT; 1956. 60 p. Boletim, n. 31.

11. Bolza $\mathrm{E}$ and Kloot NH. The mechanical properties of 174 Australian timbers. Austrália: Division of Forest Products, Research Organization; 1963. 112 p.

12. Chudnoff M. Tropical timbers of the world. Madison: United States Department of Agriculture, Forest Service; 1984. 464 p.

13. Rocco Lahr FA, Robles DG. Characterization of alternative species of wood for employment in civil construction. In: Proceedings of the 2th International Symposium on Natural Polymers and Composites; 1998; Atibaia, Brasil. Atibaia; 1998. p.115-120.

14. Rocco Lahr FA and Dias AA. Maderas tropicales brasileñas alternativas. Madera: Ciencia y Tecnologia. 1999; 1(2):7-14. ISSN 0735-205X.

15. Souza MH. Incentivo ao uso de novas madeiras para a fabricação de móveis. Brasília: IBAMA; 1997. 70 p.

16. Zenid GJ and Costa ADC. Grupamento de madeiras serradas empregadas na construção civil habitacional na cidade de São Paulo. In: Anais do 7th Encontro Brasileiro em Madeiras e em Estruturas de Madeira; 2000; São Carlos, Brasil. São Carlos, 2000. CD-ROM.
17. Finger Z, Logsdon NB and Matsubara RK. Caracterização física e dendrológica da madeira de Marupá. In: Anais do 9th Encontro Brasileiro em Madeiras e em Estruturas de Madeira; 2004; Cuiabá, Brasil. Cuiabá, 2004. CD-ROM.

18. Finger Z, Logsdon NB, Rodrigues MS and Penna ES. Cedro Rosa: Caracterização mínima da resistência e simplificada da rigidez. In: Anais do 10th Encontro Brasileiro em Madeiras e em Estruturas de Madeira; 2006; São Pedro, Brasil. São Pedro, 2006. CD-ROM.

19. Trevisan H, Tieppo FMM, Carvalho AG and Lelis RCC. Avaliação de propriedades físicas e mecânicas da madeira de cinco espécies florestais em função da deterioração em dois ambientes. Revista Árvore. 2007; 31(1):93-101.

20. Ballarin AW and Ribeiro AB. Variação da resistência à compressão paralela às fibras da madeira de E. citriodora com a umidade. In: Anais do 6th Encontro Brasileiro em Madeiras e Estruturas de Madeira; 1998; Florianópolis. Florianópolis, 1998. v. 3, p. 231-40.

21. Serpa PN, Vital BR, Lúcia RMD and Pimenta AS. Avaliação de algumas propriedades da madeira de Eucalyptus grandis, Eucalyptus saligna e Pinus elliottii. R. Árvore, Sociedade de Investigações Florestais, Viçosa, MG, v.27, n.5, p.723-733. 2003.

22. Lobão MS, Lúcia RMD, Moreira MSS and Gomes A. Caracterização das propriedades físico-mecânicas da madeira de eucalipto com diferentes densidades. Revista Árvore. 2004; 28(6):889-894.

23. Mascia TM and Rocco Lahr FA. Remarks on orthotropic elastic models applied to wood. Materials Research. 2006; 9(3):301310. http://dx.doi.org/10.1590/S1516-14392006000300010

24. Tanaami RG. Influência da umidade e da densidade em propriedades de resistência e elasticidade à flexão da madeira. [Dissertação]. São Carlos: Escola de Engenharia de São Carlos, Universidade de São Paulo; 1986.

25. Rocco Lahr FA. Considerações a respeito da variabilidade das propriedades de resistência e de elasticidade da madeira. São Carlos, SP. Tese (Livre-Docência), Escola de Engenharia de São Carlos, Universidade de São Paulo. 1990.

26. Faria OB. Influência da umidade no módulo de elasticidade longitudinal da madeira. São Carlos, SP. Dissertação de Mestrado, Escola de Engenharia de São Carlos, Universidade de São Paulo. 1993.

27. Logsdon NB. Influência da umidade nas propriedades de resistência e de rigidez da madeira. São Carlos, SP. Tese de Doutorado, Escola de Engenharia de São Carlos, Universidade de São Paulo. 1998.

28. Meyer PL. Probabilidade: Aplicações à Estatística. Rio de Janeiro, Brasil, Ao Livro Técnico, 391p. 1972. 